\title{
Climate change and food security
}

\author{
P. J. Gregory ${ }^{1, *}$, J. S. I. Ingram ${ }^{2}$ and M. Brklacich ${ }^{3}$ \\ ${ }^{1}$ Scottish Crop Research Institute, Invergowrie, Dundee DD2 5DA, UK \\ ${ }^{2}$ GECAFS International Project Office, NERC-CEH, Wallingford, Oxfordshire OX10 8BB, UK \\ ${ }^{3}$ Department of Geography and Environmental Studies, Carleton University, Ottawa, Ont., \\ Canada K1S $5 B 6$
}

\begin{abstract}
Dynamic interactions between and within the biogeophysical and human environments lead to the production, processing, distribution, preparation and consumption of food, resulting in food systems that underpin food security. Food systems encompass food availability (production, distribution and exchange), food access (affordability, allocation and preference) and food utilization (nutritional and societal values and safety), so that food security is, therefore, diminished when food systems are stressed. Such stresses may be induced by a range of factors in addition to climate change and/or other agents of environmental change (e.g. conflict, HIV/AIDS) and may be particularly severe when these factors act in combination. Urbanization and globalization are causing rapid changes to food systems.

Climate change may affect food systems in several ways ranging from direct effects on crop production (e.g. changes in rainfall leading to drought or flooding, or warmer or cooler temperatures leading to changes in the length of growing season), to changes in markets, food prices and supply chain infrastructure. The relative importance of climate change for food security differs between regions. For example, in southern Africa, climate is among the most frequently cited drivers of food insecurity because it acts both as an underlying, ongoing issue and as a short-lived shock. The low ability to cope with shocks and to mitigate long-term stresses means that coping strategies that might be available in other regions are unavailable or inappropriate. In other regions, though, such as parts of the Indo-Gangetic Plain of India, other drivers, such as labour issues and the availability and quality of ground water for irrigation, rank higher than the direct effects of climate change as factors influencing food security.

Because of the multiple socio-economic and bio-physical factors affecting food systems and hence food security, the capacity to adapt food systems to reduce their vulnerability to climate change is not uniform. Improved systems of food production, food distribution and economic access may all contribute to food systems adapted to cope with climate change, but in adopting such changes it will be important to ensure that they contribute to sustainability. Agriculture is a major contributor of the greenhouse gases methane $\left(\mathrm{CH}_{4}\right)$ and nitrous oxide $\left(\mathrm{N}_{2} \mathrm{O}\right)$, so that regionally derived policies promoting adapted food systems need to mitigate further climate change.
\end{abstract}

Keywords: adaptation; coping strategies; feedbacks; environmental change; food systems; vulnerability

\section{INTRODUCTION}

The links between climate change and food security have, to date, largely been explored in relation to impacts on crop productivity and hence, food production. For instance, Gregory et al. (1999) summarized experimental findings on wheat and rice that indicated decreased crop duration (and hence yield) of wheat as a consequence of warming and reductions in yields of rice of about $5 \%{ }^{\circ} \mathrm{C}^{-1}$ rise above $32{ }^{\circ} \mathrm{C}$. These effects of temperature were considered sufficiently detrimental that they would largely offset any increase in yield as a consequence of increased atmospheric carbon dioxide $\left(\mathrm{CO}_{2}\right)$ concentration. Several reviews (e.g. Amthor 2001; Fuhrer 2003) have further assessed the potential consequences of changes in climate on the

* Author for correspondence (peter.gregory@scri.ac.uk).

One contribution of 17 to a Discussion Meeting Issue 'Food crops in a changing climate'. growth and yield of crop plants, concluding that the earlier-anticipated benefits of $\mathrm{CO}_{2}$ fertilization would be largely offset by nutrient limitations, pollutants and further interactions with climatic factors (see also Long et al. 2005). Similarly, simulations of maize production in Africa and Latin America using climate data from the HadCM2 model to generate characteristic daily weather data for 2055 predicted an overall reduction of $10 \%$ (Jones \& Thornton 2003). This, and other similar projections, uses a process-based crop production model (such as the crop environment resource synthesis family) to link climate to plant physiological processes. Yield can then be modelled for a uniform crop and upscaled to a larger area normally within some form of geographic information system (GIS). The aggregate result of Jones \& Thornton (2003), though, hides considerable variability within and between countries, and, as they point out, also ignores the fact that maize is commonly used as fodder as well as food as part of a complex production system. 

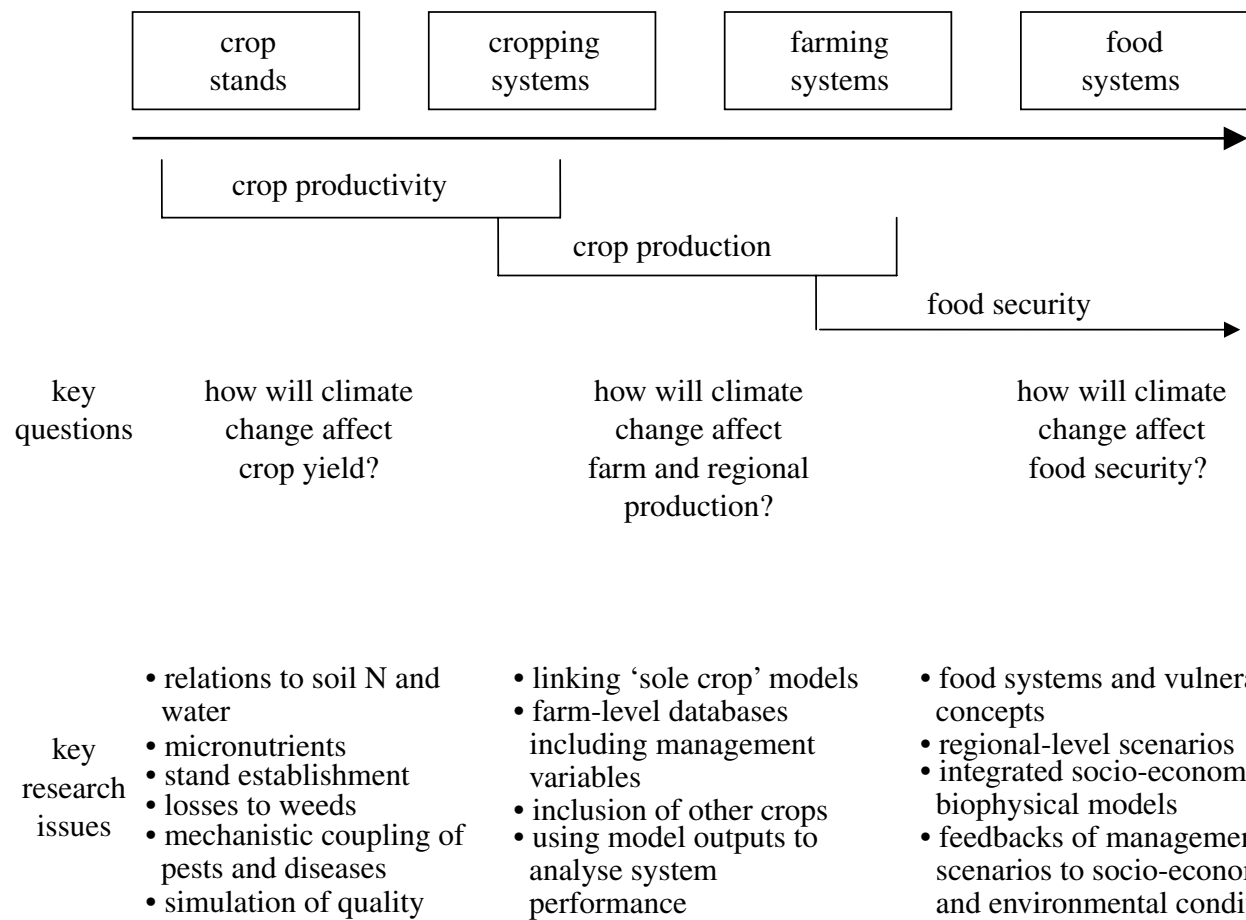

- linking ‘sole crop' models
- farm-level databases
including management
variables
- inclusion of other crops
- using model outputs to
analyse system
performance

- linking 'sole crop' models

- farm-level databases variables

- inclusion of other crops

analyse system

\author{
- food systems and vulnerability \\ concepts \\ - regional-level scenarios \\ - integrated socio-economic- \\ biophysical models \\ - feedbacks of management \\ scenarios to socio-economic \\ and environmental conditions
}

Figure 1. The changing nature of key research issues and frequently asked questions at a range of different scales moving from crop production to food security.

The spatial variation in effects of climate change was an explicit component of the study on potential yields of rainfed cereal crops undertaken by Fischer et al. (2001). In this analysis, climate predictions in 2080 were obtained from various global circulation models (GCMs) and assessments made based on current populations and socio-economic conditions. The output demonstrated that cereal producing regions of Canada, and northern Europe and Russia might be expected to increase production as a consequence of the climate changes predicted by GCMs, while many parts of the world would suffer losses including the western edge of the USA prairies, eastern Brazil and western Australia. Overall, the results of this and subsequent work that included assessments of future populations and alternative future socio-economic conditions (Fischer et al. 2002a,b, 2005), demonstrated that climate change would benefit the developed countries more than the developing countries even if cropping practices evolved to allow more than one rainfed crop per year. Moreover, the anticipated demographic growth and socio-economic development in these developing countries would result in substantial increases in food requirements thereby exacerbating the detrimental effects of climate change.

The spectre of climate change, together with other global environmental changes such as changes in water availability, and land cover, and altered nitrogen availability and cycling (all strongly influenced by human activities), has increased concerns about achieving food security especially for poor people (Gregory \& Ingram 2000; Parry et al. 2001; Rosegrant $\&$ Cline 2003). There is also concern that meeting the global demand for food resulting from higher population and changing dietary preferences will further degrade the environment both through additional destruction of native vegetation and increased intensification of cropped areas (Tilman et al. 2001). This may, in turn, further undermine the food systems upon which food security is based.

While there has been considerable progress in understanding the sensitivities of crop yield to climate change, assessments of climate change effects on food security remain rather limited. Food security is concerned not only with food availability but also with access to and utilization of, food so that studies, which focus only on crop production provide only a partial assessment of food security-climate change relationships. This is of particular concern as many of the policy-based issues that are relevant to the international and sustainable development communities are posed in the context of food security prospects. Engagement of these policy communities requires a much broader and comprehensive research framework.

Recognition that food security depends on robust food systems that encompass issues of availability, access and utilization (not merely production alone), and consequently that the nature of key research issues changes as questions more related to food security are formulated (figure 1), led the international global change research community to establish the joint project global environmental change and food systems (GECAFS) in 2001. GECAFS is an interdisciplinary research programme that aims to improve understanding of the relationship between food systems and the earth system to deliver science-based tools for analysing socio-economic and environmental consequences of strategies seeking to adapt to climate and other environmental changes. The purposes of this paper are to: (i) outline the notion of food systems, their relation to food security, and links to climate change; (ii) explore the vulnerability of food systems to environmental change; (iii) examine some prospects for adaptation 
of food systems in response to climate change and (iv) highlight some of the environmental feedbacks resulting from modifications to food systems. The paper will draw on results of the conceptual and regional research initiated by GECAFS (Ingram et al. 2005).

\section{FOOD SECURITY, FOOD SYSTEMS AND THE LINK TO CLIMATE}

There are several definitions of what constitutes food systems each formulated in relation to a specific range of issues (e.g. globalization of the agri-food system, Goodman 1997; community food systems, Gillespie \& Gillespie 2000; ecological interests, Francis et al. 2003). For GECAFSs purpose, food systems are defined as a set of dynamic interactions between and within the biogeophysical and human environments which result in the production, processing, distribution, preparation and consumption of food. They encompass components of: (i) food availability (with elements related to production, distribution and exchange); (ii) food access (with elements related to affordability, allocation and preference) and (iii) food utilization (with elements related to nutritional value, social value and food safety (figure 2)). Food systems, then, involve much broader considerations than productivity and production alone. They underpin food security, which is the state achieved when food systems operate such that 'all people, at all times, have physical and economic access to sufficient, safe and nutritious food to meet their dietary needs and food preferences for an active and healthy life' (FAO 1996). Food security is diminished when food systems are stressed. This can be caused by a range of factors in addition to climate and other environmental changes (e.g. conflict, changes in international trade agreements and policies, HIV/AIDS) and may be particularly severe when these factors act in combination. Access to culturally acceptable food by individuals and communities, or means for its procurement, is increasingly being elaborated into human rights legislation (McClain-Nhlapo 2004).

Food systems may be simple, as in the case of a subsistence farmer who produces, processes and consumes food on farm. However, there are comparatively few individuals or households in the world that are totally self-reliant for food throughout a year, and in almost all cases there is an element of bartering, exchange, or the cash economy to bring food into the household. In many places, the food system has changed radically in the last century and continues to become increasingly complex (Millstone \& Lang 2003; Barling 2004). The intensification of agricultural production, since the 1940s has been accompanied by profound changes in the organization of food systems around the world including changes in distribution, marketing, affordability and preferences for particular food items. These changes are especially obvious in the USA and Europe, where market globalization has occurred with global sourcing of products by retailers direct from producers in the case of fresh fruit and vegetables and from a few, large manufacturers for other food products. Such changes have also shifted economic and political power from farmers to retailers,

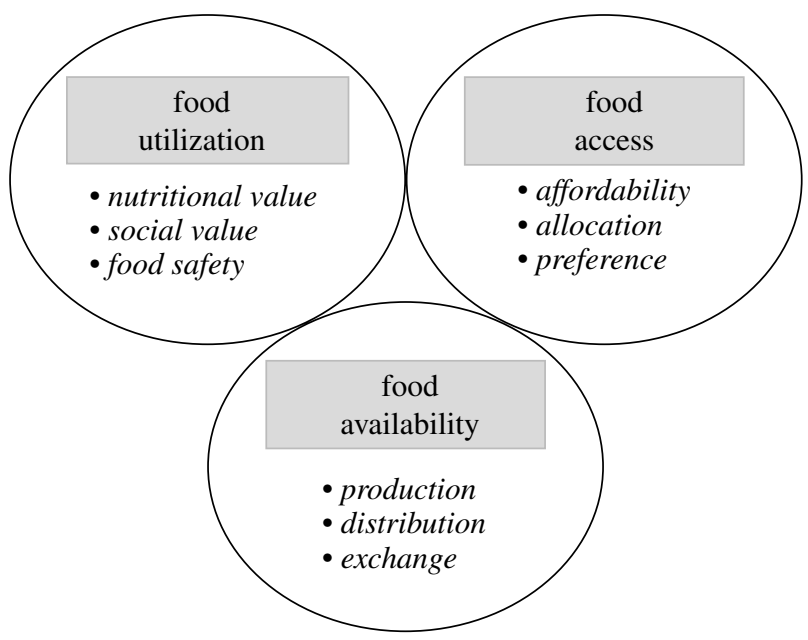

Figure 2. The three components of food systems with their main elements shown in italics. (From Ingram et al. 2005.)

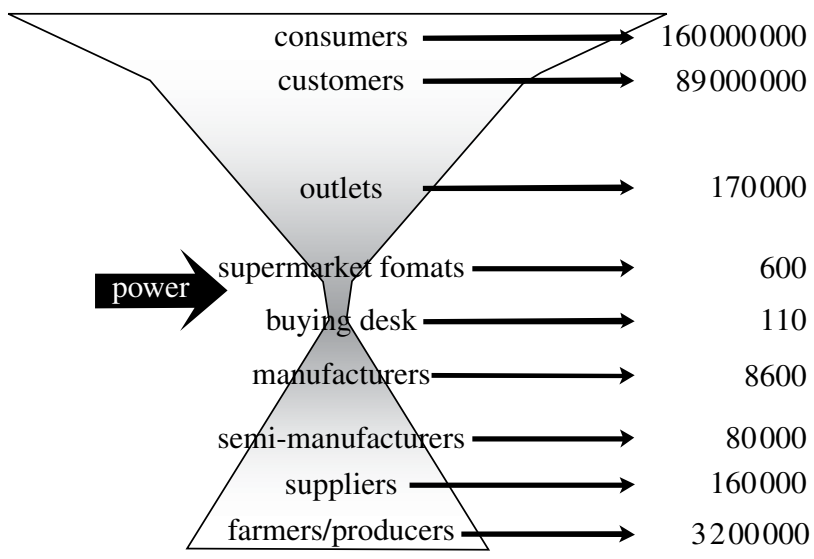

Figure 3. Components of the food chain in selected OECD countries of Europe indicating the two inverted pyramid structure that relates farmers to consumers. (From Grievink 2003.)

from national legislative bodies to regional and global organizations, and from the state to multinational corporations. For example, in a study of selected OECD countries in Europe, Grievink (2003) determined that the food chain has some 160 million consumers of whom about 3.2 million are also farmers or food producers, but the link between these groups is increasingly determined by the small number of food processors/manufacturers (about 90000 ) and the even smaller number of buyers (about 100) for the supermarket chains (figure 3).

Food systems around the world are changing very rapidly as urbanization and globalization proceed apace. The urbanization of many predominantly rural countries in the last three decades has been accompanied by the rapid growth of supermarkets in many, often accompanied by foreign investment by global retail chains (Reardon et al. 2003). However, even in poor countries such as Kenya, where per capita gross domestic product (GDP) was less than $\$ 400 \mathrm{yr}^{-1}$ in 2002, supermarkets have grown from a tiny niche market in 1997 to be greater than $20 \%$ of urban food retailing today (Neven \& Reardon 2004). This growth has been a consequence of three major factors. First, rapid urbanization has seen the proportion of the 
Table 1. Changes in the supply of fresh fruit and vegetables to the Uchimi supermarket chain in Kenya by supplier type for the period 1997-2008.

(Values are the percentage contribution to the total supply (from Neven \& Reardon 2004).)

\begin{tabular}{|c|c|c|c|c|c|c|}
\hline \multirow[b]{2}{*}{ type of supplier } & \multicolumn{3}{|c|}{ vegetables } & \multicolumn{3}{|l|}{ fruits } \\
\hline & 1997 & 2003 & 2008 & 1997 & 2003 & 2008 \\
\hline small farms & 13 & 10 & 15 & 5 & 10 & 10 \\
\hline medium farms & 10 & 25 & 30 & 10 & 10 & 10 \\
\hline large farms and plantations & 5 & 15 & 35 & 0 & 15 & 35 \\
\hline traditional brokers/wholesalers & 70 & 45 & 10 & 70 & 40 & 10 \\
\hline imports & 2 & 5 & 10 & 15 & 25 & 35 \\
\hline
\end{tabular}

population based in urban areas grow from 0.13 in 1975 to 0.36 in 2000 with an expectation of greater than 0.5 in 2013; second, trade and domestic market liberalization, since 1993 has seen the removal of import controls and the deregulation of prices and third, movement towards price-based competition between the indigenous chains. Success within Kenya is now spreading to other East African countries with important effects on the market conditions faced by farmers including the decline of traditional wholesalers (and the smallholder producers from whom they buy) and the increase in direct purchases from larger farms (table 1; Neven \& Reardon 2004).

These marked changes in access and utilization of food around the world provide a context in which to evaluate the likely effects of climate and other environmental changes on crop production and food security. Not all food systems or parts of food systems are equally vulnerable to environmental changes because the capacity to cope with existing variability in bio-physical and socio-economic systems, and the ability of humans to perceive environmental changes and to adapt food systems, differs. Human vulnerability includes both the likelihood of exposure to stresses as well as the capacity to cope with such stresses (i.e. sensitivity). Vulnerability and poverty are often interrelated because both the likelihood of exposure to stresses is greater among the poor and because a large proportion of their resources are spent either purchasing or producing food, thereby reducing their capacity to cope with perturbations (Hume et al. 2001). Moreover, pursuit of food security frequently involves trade-offs with expenditure on health and education reducing still further the ability to improve longer-term living conditions or resilience to stress and shock (Boudreau 1998). Food insecurity is experienced at a range of spatial scales from individual households to regions, as well as a range of time-scales, and reductions of vulnerability at one scale do not automatically flow to the next scale. For example, regional policy decisions do not always convert to successful local implementation especially if distribution services are inadequate, or food preferences are ignored (Ellis 2003).

Climate variation is one of several interacting factors that affect food security. For example, in studies of household food security in southern Africa, climate/environment was only one of some 33 drivers mentioned as important by householders (Misselhorn 2005). The mix of drivers varied across the region but in all

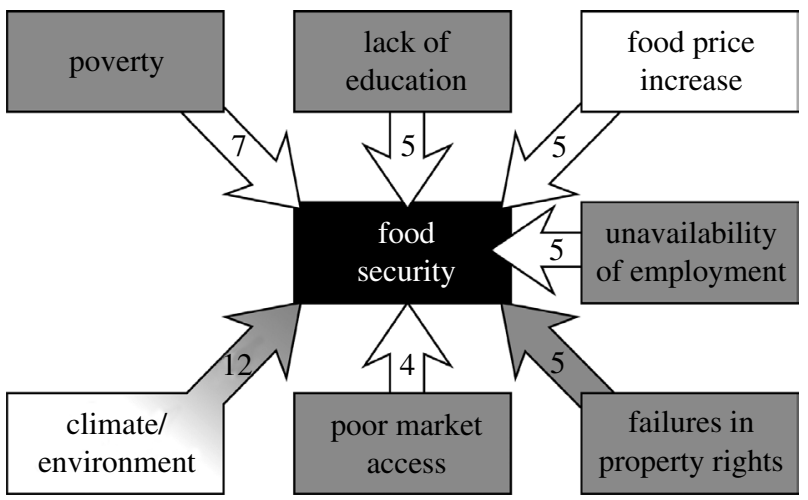

Figure 4. The seven most frequently cited drivers in 49 studies of household-level food insecurity in southern Africa. The numbers in the arrows indicate the number of citations, as a percentage of 555 citations of 33 possible drivers. The drivers shaded in grey were noted as being chronic, while those in white indicate drivers experienced mainly as 'shocks'. The shaded arrows indicate drivers that acted primarily via reductions in food production, while the white arrows indicate those which acted by restricting access to food. (From Scholes \& Biggs 2004.)

communities many interacting factors resulted in vulnerability to food shortages. Overall, however, climate/environment was one of the seven factors influencing food security that were frequently cited (figure 4; Scholes \& Biggs 2004), because of its role both as an ongoing issue (57\% of cases, where it was mentioned) and as a 'shock' (43\%). The impacts of sudden shocks such as drought are felt, then, on top of ongoing long-term stresses, and the low ability to cope with such shocks and to mitigate long-term stresses means that the employment of coping strategies that might be available to others, is at a too high cost or, simply, unavailable. Typically, reliance on purchased food increases in drought years due to losses in food production leading to an increase in poverty due to the synergistic action of other drivers such as rising food prices and unemployment. Scholes \& Biggs (2004) record that the food security crisis in southern Africa in 2002-2003 was not simply a result of drought alone and, indeed, climatic stress was not as severe as in previous crises. Maize production during the preceding growing season was only $5.5 \%$ less than the previous five year average so food stocks at the start of the climatic shock were not unusually low. It was concluded that the crisis was indicative of entrenched vulnerability resulting from a range of regional and 
global political and economic factors (Vogel \& Smith 2002) including high food prices, legacies of structural adjustment, government policies, conflict and war, policies on genetically modified foods, and poor responses to the HIV/AIDS pandemic. The key here was that conditions, which weakened food systems in the region were already in place. The moderate climatic shock intensified food insecurity and the long-term vulnerability of the region.

\section{VULNERABILITY OF FOOD SYSTEMS TO CLIMATE CHANGE}

Much climatic change-agricultural research has been focused on assessing the sensitivity of various attributes of crop systems (e.g. land suitability, crop yields, pest regimes) to specified changes in climate. These partial assessments most often consider climate change in isolation, focus on bio-physical aspects of production, and provide little insight into the food accessibility and food utilization dimensions of food security. To better address the food security concerns that are central to economic and sustainable development agendas, it is desirable to develop a broader research framework, which integrates bio-physical and socio-economic aspects of food systems and thereby addresses key questions including:

(i) which aspects of food systems are most vulnerable to climate change? and

(ii) what can be done to reduce the vulnerability of these food systems and thereby improve food security?

The roots of vulnerability science can be traced back to famine (for example, see Watts \& Bohle 1993) and natural hazards (for example, see Mustafa 1998) but concepts developed in these areas have, to date, not been fully incorporated into climatic change/global environmental change studies. It has become clear from famine and hazards research that the key to assessing vulnerability is to develop research frameworks which can explicitly consider the social, economic and political constraints which condition the capacity of human systems (including food systems) to cope with external stressors such as climatic change, along with the magnitude and frequency of environmental stresses imposed on the system. For GECAFS, these concepts have been extended to consider environmental vulnerability (i.e. stresses originating from drought, storms and landslides and other such phenomena) and social vulnerability (i.e. the capacity of communities to cope with and recover from environmental stresses). Figure 5 (derived from Bohle 2001; Brklacich \& Bohle 2005; Wisner et al. 2004) shows that the vulnerability of food systems is not determined by the nature and magnitude of environmental stress per se, but by the combination of the societal capacity to cope with, and/or recover from environmental change, coupled with the degree of exposure to stress. While the coping capacity and degree of exposure is related to environmental changes, they are both also related to changes

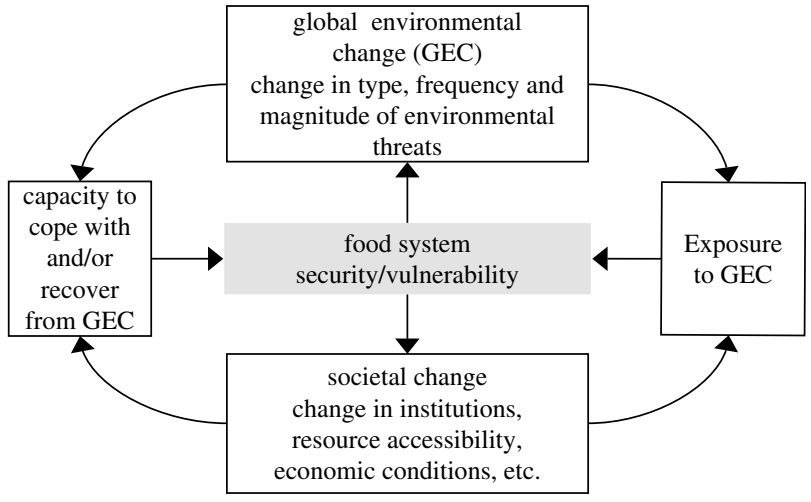

Figure 5. Factors determining the vulnerability of food systems to GEC. (From Ingram et al. 2005.)

in societal aspects such as institutions and resource accessibility (Adger 1999). Finally, changes in the food system aimed at reducing vulnerability feed back to environmental and societal changes themselves. They may, for example, reinforce agricultural practices that either reduce or exacerbate land degradation, and increase or reduce farm profitability.

Initial research in the Indo-Gangetic Plain (IGP) has used this more integrated approach to help define the vulnerability of the region's food systems (Aggarwal et al. 2004). It has demonstrated that the conditions underpinning vulnerability are not uniform throughout the region. In the western IGP (a region of general surplus production), food systems are most vulnerable to issues related to the availability of water; excessive irrigation has lead to rising watertables and soil salinization in some areas while in others water shortage has resulted in falling watertables, rapidly increasing costs of pumping and shortage of drinking water. In the eastern IGP, resource poor farmers, who have very limited options to cope with and recover from external stresses, are most vulnerable to environmental changes such as rising sea-level, and climate change and climate variability leading to increased risk of flooding. Overall, this analysis suggests that food insecurity concerns cannot be effectively addressed by a single region-wide policy.

\section{ADAPTATION: REDUCING THE VULNERABILITY OF FOOD SYSTEMS TO CLIMATE CHANGE}

Development of human societies has involved a continuous process of adapting to changing stresses and opportunities. While climate change is seen as a relatively recent phenomenon, individuals and societies are used to adapting to a range of environmental and socio-economic stresses. In many parts of the world, and especially in semi-arid lands, there is an accumulated experience with phenomenon such as drought. As climate extremes are predicted to increase in frequency and intensity in future, it is important to understand and learn from relevant past adaptations and indigenous knowledge. However, changes in climate variability and mean values will bring additional complications to many, especially those dependent on food systems that are particularly vulnerable to these additional stresses. 
Food systems fail to deliver food security when related determinants, and/or the links between them, are disrupted by climate change or other stresses (figure 2). The food systems approach to research on food security allows for adaptation options aimed at reducing vulnerability to be considered in terms of any of these determinants and the stresses acting upon them. Adaptations may occur in relation to, for instance, agronomic or fisheries aspects regarding food production; or government-set prices and incomes concerning access to food; or changes in societal values concerning food utilization. The key issues for adapting food systems to reduce their vulnerability to climate change are to:

(i) identify which related determinants are particularly sensitive to GEC;

(ii) enhance effective related determinants; and

(iii) restore disrupted related determinants.

To translate these theoretical considerations into practice requires research to:

(i) identify and evaluate the possible adaptations mechanisms to reduce food system vulnerability to climate change;

(ii) identify, document and learn from past and current coping mechanisms employed by vulnerable groups in their day-to-day food supply systems;

(iii) analyse and strengthen the capability of communities and countries to adapt as much as possible; and

(iv) identify the most suitable level at which each adaptation strategy should be implemented (e.g. regional, national or local intervention).

These points are illustrated below using an example from each of the three elements of the food system as depicted in figure 2 .

\section{(a) Reducing food system vulnerability by increasing food production}

Past increases in agricultural production have occurred as a result of both extensification (altering natural ecosystems to generate products) and intensification (producing more of the desired products per unit area of land already used for agriculture; Gregory \& Ingram 2000). In future, intensification will be the dominant means for increasing production although the cultivation of new land will be important in some regions (e.g. an estimated contribution of $47 \%$ from extensification in sub-Saharan Africa to cereal production by 2020; Alexandratos 1995). Increased yields per unit area, with a smaller contribution from an increased number of crops grown in a seasonal cycle, is expected to be the main way in which crop production will rise to meet demand (Gregory et al. 2002). In the recent past, such increases have been achieved by a 'unique conjunction of three innovations', namely cheap nitrogenous fertilizers combined with semi-dwarf genotypes of cereals, effective weed control with herbicides, and the expansion of irrigation (Evans 1998). For the future, continued technological developments are anticipated to facilitate the adaptation of crops to changing environments.
Porter \& Semenov (2005) has described some of the plant traits that may permit adaptation to climate change. An area in which progress may be possible is in improved selection of genotypes that utilize limited supplies of water stored in soils; less rainfall may be a consequence of climate change or increased climate variability in some regions. There are many plant characters and elements of crop management that contribute to the efficient use of water by crops (Gregory 2004), but relatively little attention has been paid to root characters that may allow more water to be exploited or used more efficiently, largely because root systems are very difficult to measure. However, genotypic differences are known to exist in many features of root systems (e.g. depth of rooting, rate of downward extension, diameter of roots, total length) which may be exploitable to improve crop yield in drier climates (O'Toole \& Bland 1987). Studies with existing genotypes in dry areas may inform the adaptation possible under conditions of changed climate. For example, in the Mediterranean environment of northern Syria, crops are largely dependent on the use of growing season rainfall (very little water is stored from season to season). Studies of the root growth, water use and yield of the local landrace (Arabic abiad) at sites with typically less than $350 \mathrm{~mm}$ annual rainfall, showed that this genotype consistently had greater root lengths per unit soil volume at depths below $15 \mathrm{~cm}$ than other genotypes such as the variety Beecher (figure 6), and that this was associated with greater water uptake in the 3-4 weeks before anthesis. In this environment, faster rates of growth before anthesis were reflected in higher crop yields; senescence of the crop before the grains could fill ('haying off') was not observed. The development of DNA-based molecular markers has opened up opportunities for identifying the genetic factors (quantitative trait loci) underpinning various root traits. Again, this science is at an early stage of development for root traits, but significant progress has been made in studies of drought tolerance with rice (Champoux et al. 1995; Babu et al. 2001).

\section{(b) Reducing food system vulnerability by improving food distribution}

Infrastructural and non-infrastructural controls on food distribution can be significant impediments to reducing food system vulnerability in a timely manner. This became strikingly apparent during the drought relief effort mounted in 1990/1991 in southern Africa in response to the estimated 86 million people at risk in the region (of whom some 20 millions were deemed at 'serious risk').

A massive international food aid programme was launched with food to be delivered via a number of rail 'corridors' from the region's major ports to the hinterland. Nearly, 8 million tonnes of food grains were imported by the relief programme for the 10 countries affected; this was almost four times the normal annual rate of imports for the region (Muchero 2003). This substantial increase in imports resulted in pressure on the region's distribution systems, leading to a number of problems which would not have been significant in 'normal' years. These are well illustrated by examples taken from the Maputo and Beira corridor. Infrastructural constraints included ongoing rehabilitation, physical impediments (steep gradients and 


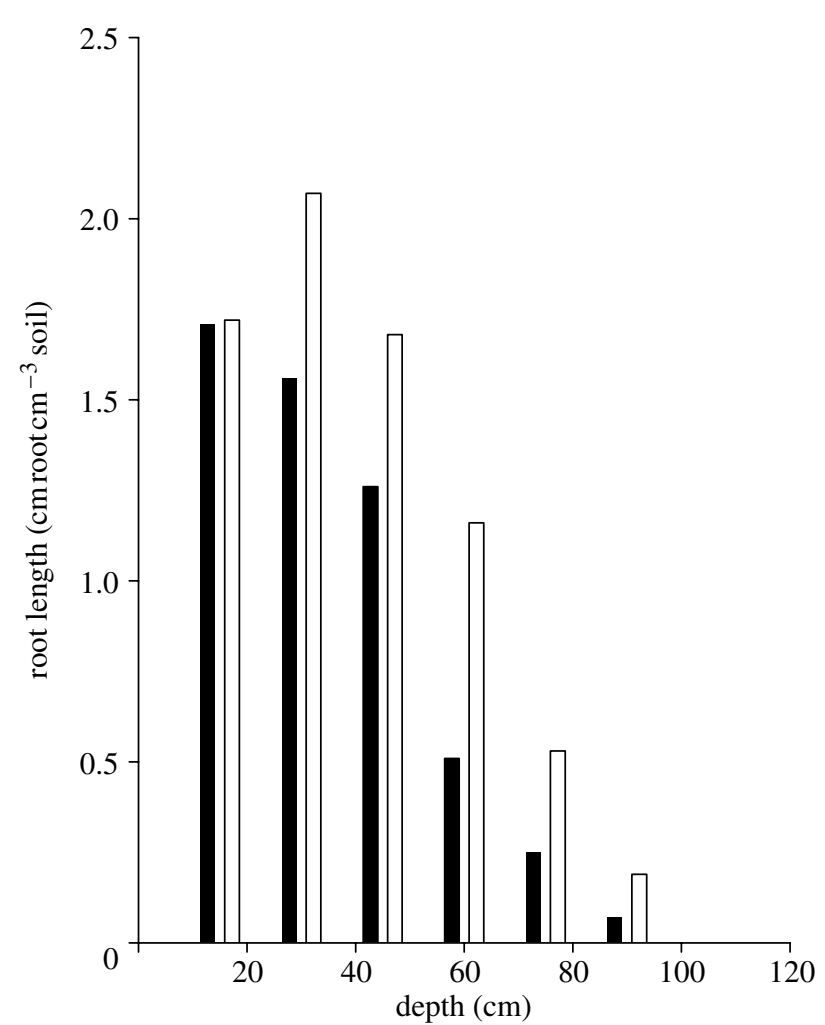

Figure 6. The distribution of root length with soil depth for the barley genotypes Arabic abiad (white bar) and Beecher (black bar). The distributions are the average for two sites in northern Syria with contrasting soils and rainfall (adapted from Gregory 1989).

tight curves at which points grain was stolen from the slow-moving wagons), a shortage of bags and tarpaulins, the need to tranship Malawi-bound cargo in Harare, and a shortage of rolling stock and locomotive power. In addition, a number of non-infrastructural constraints further complicated the situation. These included general security problems along the corridor, regulatory constraints for cargo destined for Zambia, conflict between humanitarian requirements and commercial concerns, poor labour management systems in ports (where there were no incentives to work more than necessary), and transit toll fees in Mozambique.

Food availability for the region was severely constrained due not to lack of food per se (there were ships queuing at anchor to unload), but by lack of investment in distribution systems and institutional constraints. This brief summary highlights several ways in which regional food insecurity could be reduced, and shows that adaptation options can include a range of issues including, among others, regional investment in port, rail and grain storage infrastructure and in region-wide political agreements to facilitate the flow of food in an emergency.

\section{(c) Reducing food system vulnerability}

by increasing economic access to food

Improved economic access to food is an important development goal, but the means of achieving it and the consequences of strategies aimed at its achievement are the subject of much discussion. In the case of southern Africa, Arntzen et al. (2004) indicate that the discussion centres around varied means. First, price mechanisms and policies could be designed that serve the interest of producers (incentive to produce more food) and consumers (to facilitate access to food). Second, regional specialization in food production and regional trade would lower production costs and food prices and, therefore, improve access. This important adaptation is as yet hardly pursued, but should gain momentum with trade liberalization and policy shifts towards food security. Third, economic growth will lead to income and employment generation, both of which will facilitate access to food. Finally, stability and governance supported by an effective pool of human and institutional resources facilitate the establishment and maintenance of food systems.

In south Asia, studies have examined how income growth has led to changes in diets away from traditional foods. This may have negative impacts on local farmers who grow traditional foods and are not well integrated into markets (Pingali \& Khawaja 2004). The impact of trade liberalization on the poor is a topic of current study, but there is an emerging consensus that they should be protected from negative impacts through the implementation of safety nets (Mahendra Dev et al. 2004).

\section{FEEDBACKS FROM ADAPTATION OPTIONS TO THE GLOBAL ENVIRONMENT}

In attempting to adapt food systems to cope with climate and other environmental changes, it will be important to ensure that the changes proposed do not exacerbate climate change or other aspects of environmental degradation (i.e. that they contribute to sustainability). Past extensification (land cover change, especially the removal of trees) has made a large contribution to $\mathrm{CO}_{2}$ emissions so that one means of mitigating further emissions is to intensify production on existing cleared areas and leave forests intact. Nelson \& Maredia (1999) estimated that the introduction of high-yielding varieties as part of the 'green revolution' saved $170 \mathrm{Mha}$ of forest from cropping in Africa, Asia and Latin America in the period 1970-1990. Assuming an average carbon stock of $100 \mathrm{Mg} \mathrm{Cha}^{-1}$, this represents a saving of $17 \mathrm{Gt}$ of carbon, equivalent to 2-3 years of total global carbon (C) emissions. Intensification can, then, contribute to reducing $\mathrm{CO}_{2}$ emissions, although this saving is partially offset by the increased C costs of the new production system. Previous intensification via high-input technologies has resulted in detrimental environmental consequences such as reduced biodiversity and water pollution in some areas (Matson et al. 1997), resulting in substantial concerns about the environmental consequences of meeting projected demands for food by 2050 (Tilman et al. 2001). This has led to moves in many parts of the world towards intensive systems that are both high yielding and more environmentally benign (Gregory et al. 2002). Such systems encourage the greater efficiency of use of inputs to minimize both on- and off-site environmental consequences but are yet to be widely adopted.

Gregory et al. (2002) suggested that regional changes in climate can be induced by both extensification (through effects on albedo and changes in latent/sensible heat balances) and intensification. Crop intensification 
Table 2. Cereal yields $\left(\mathrm{t} \mathrm{ha}^{-1}\right.$ ) and estimated total annual (on-site) emissions of greenhouse gases (kg C-equivalent ha ${ }^{-1}$ ) from irrigated rice-wheat systems in the Indo-Gangetic Plain in terms of carbon equivalents (from Grace et al. 2003).

(Carbon equivalent calculated based on $\mathrm{CO}_{2}$ released during all agricultural operations. A global warming potential of 21 and 310 was used for $\mathrm{CH}_{4}$ and $\mathrm{N}_{2} \mathrm{O}$, respectively. FYM, farmyard manure.)

\begin{tabular}{|c|c|c|c|}
\hline treatments & no fertilizer & recommended fertilizer & recommended + FYM \\
\hline rice yield $\left(\mathrm{tha}^{-1}\right)$ & 3.74 & 5.67 & 6.41 \\
\hline wheat yield $\left(\mathrm{t} \mathrm{ha}^{-1}\right)$ & 1.71 & 3.97 & 4.60 \\
\hline $\begin{array}{l}\text { conventional tillage and resides retained } \\
\left(\mathrm{kg} \mathrm{C} \text {-equivalent } \mathrm{ha}^{-1}\right)\end{array}$ & 3496 & 4721 & 7137 \\
\hline $\begin{array}{l}\text { conventional tillage and residues burnt } \\
\left(\mathrm{kg} \text { C-equivalent } \mathrm{ha}^{-1}\right)\end{array}$ & 3953 & 5510 & 8032 \\
\hline $\begin{array}{l}\text { no tillage and residues retained } \\
\left(\mathrm{kg} \mathrm{C} \text {-equivalent } \mathrm{ha}^{-1)}\right.\end{array}$ & 2966 & 4362 & 6724 \\
\hline
\end{tabular}

Table 3. Agriculture's contribution to greenhouse gas emissions (adapted from Bruinsma 2003).

\begin{tabular}{llll}
\hline & $\mathrm{CO}_{2}$ & $\mathrm{CH}_{4}$ & $\mathrm{~N}_{2} \mathrm{O}$ \\
\hline $\begin{array}{l}\text { agricultural emissions as \% of total } \\
\text { anthropogenic sources }\end{array}$ & 15 & 49 & 66 \\
$\begin{array}{l}\text { expected changes in agricultural emissions } \\
\text { to } 2030\end{array}$ & stable or declining & from rice: stable or declining & $35-60 \%$ increase \\
& & from livestock: $60 \%$ increase & \\
\hline
\end{tabular}

has biogeophysical effects through changes in physical and physiological properties at the surface, in landscape heterogeneity, and in the production of dust, and biogeochemical effects through production of greenhouse gases and organic aerosols. For example, in the IGP, the increased adoption of the rice-wheat system during the last three decades has resulted in the heavy use of irrigation, fertilizers, electricity and diesel (Aggarwal et al. 2004). These practices have had a direct impact on the emissions of greenhouse gases (especially $\mathrm{CO}_{2}$, $\mathrm{CH}_{4}$ and $\mathrm{N}_{2} \mathrm{O}$ ). Depending on the management practices used, emissions are estimated collectively to have a global warming potential equivalent to 3000 $8000 \mathrm{~kg} \mathrm{C} \mathrm{ha}^{-1} \mathrm{yr}^{-1}$ (Grace et al. 2003; table 2). This amounts to a significant quantity of $\mathrm{C}$ for the whole IGP. While increasing production in the future may further increase emissions if no changes in practice are wrought, alternative management strategies could effectively reduce emissions. For example, surface seeding and/or zero-tillage, and the establishment of upland crops after rice gives similar yields to crops planted under normal conventional tillage over a diverse set of soil conditions, but reduces costs of production and allows earlier planting which offers higher yields. The practice also results in less weed growth and increases the efficiency of water and fertilizer use. Moreover, it reduces the use of natural resources such as steel for tractor parts and fuel because zero tillage saves 29.91 of diesel per hectare compared to conventional tillage (equivalent to $21.2 \mathrm{~kg} \mathrm{C} \mathrm{ha}^{-1} \mathrm{a}^{-1}$ reduction). In addition, resourceconserving technologies restrict the oxidation of soil carbon thus mitigating increases of $\mathrm{CO}_{2}$ into the atmosphere.

Table 3 demonstrates the important contribution that agriculture makes to emissions of $\mathrm{N}_{2} \mathrm{O}$, a greenhouse gas that is about 200 times as radiatively active as $\mathrm{CO}_{2}$. Much of this comes from applications of nitrogen $(\mathrm{N})$ fertilizers which have increased substantially as crop intensification has proceeded (Matson et al. 1997). Smith et al. (1997) estimated that of the $3.5 \mathrm{Tg} \mathrm{N}$ released annually from cultivated land as $\mathrm{N}_{2} \mathrm{O}$, about $1.5 \mathrm{Tg}$ was directly attributable to synthetic $\mathrm{N}$ fertilizers, with an additional $0.5-5 \mathrm{Tg} \mathrm{N}$ emitted as NO. Reducing the quantities of $\mathrm{N}_{2} \mathrm{O}$ emitted from fertilizer applications may, though, be difficult. Adoption of the best available agronomic practices such as soil testing to match supply with demand and optimizing tillage and drainage, can reduce emissions but such practices would still be insufficient to offset the increases expected from the increased global use of $\mathrm{N}$ fertilizers (Smith et al. 1997). This poses a considerable challenge for the future sustainability of food systems.

A further environmental feedback that is an issue in some regions is the changes in groundwater availability as a consequence of water extraction for irrigation in intensive crop production systems. For example, in the Punjab province of India, extraction has led to significantly lower watertables (table 4); these are expected to fall even further in the future. In addition to changes in aquifer and surface water dynamics per se, a significant consequence of this is the need to use ever increasing amounts of power (diesel and/or electric pumps) to access this dwindling resource. This, in turn, gives rise to increased $\mathrm{CO}_{2}$ emissions.

The full range of environmental feedbacks that will result from adapting food systems are presently difficult to discern because there is no consensus yet as to how climate change impacts will manifest themselves at different scales. The possible environmental impacts of adaptations include: (i) changes in biodiversity due to extension of the agricultural frontier; (ii) water pollution associated with increased use of fertilizers and pesticides; (iii) waterlogging, salinization and water scarcity due to irrigation and (iv) land degradation due to use of less suitable land. However, there is no reason to suppose that the effects should be so uniformly negative if 
Table 4. Measured water table depths (m) in Punjab, India (adapted from Sidhu 2005).

\begin{tabular}{lcr}
\hline & \multicolumn{2}{c}{ measured } \\
\cline { 2 - 3 } zones & 1993 & 2003 \\
\hline sub-montane zone (district average) & 17.6 & 18.5 \\
central zone (Sangur district) & 13.8 & 20.6 \\
central zone (Patiala district) & 11.7 & 18.4 \\
central zone (Moga district) & 9.4 & 18.6 \\
southwest zone (district average) & 6.8 & 8.9 \\
\hline
\end{tabular}

institutional support is given to more sustainable practices. The increasing concerns of human societies in Europe, North America and elsewhere to utilize land for food and other purposes (e.g. recreation, wildlife) suggests that greater emphasis will be placed on more efficient use of inputs than hitherto with consequent reductions in pollution and environmental degradation.

\section{CONCLUDING REMARKS}

In 2000, the member states of the United Nations committed themselves to eight Millennium Development Goals, each with specific, measurable targets that should be met by 2015 . The first goal, that of eradicating extreme hunger and poverty calls for halving of hunger and poverty by 2015 in relation to 1990 . This goal specifically recognizes the agriculture-hunger-poverty nexus and the limited coping capability that poverty induces. While increased agricultural productivity is a key step in reducing rural poverty (Von Braun et al. 2004), favourable macro-economic and trade policies, good infrastructure, and access to credit, land and markets are also required for fast rates of growth. Climate change will add a further dimension to the challenge of ensuring food security for all with the poor most vulnerable because of their restricted options for coping.

This paper demonstrates that climate change is only one of several changes affecting food systems and that its relative importance varies both between regions and between different societal groups within a region. Adaptations of food systems via interventions in availability, access and utilization are possible to cope with climate change at different scales although their feedbacks to the earth system have yet to be fully assessed.

We thank the Natural Environment Research Council (NERC) for continued financial support for our work, and colleagues in the international research projects Global Change and Terrestrial Ecosystems Focus 3 and Global Environmental Change and Food Systems for access to ideas and data underpinning this paper.

\section{REFERENCES}

Adger, N. 1999 Social vulnerability to climate change and extremes in coastal Vietnam. World Dev. 27, 249-269. (doi:10.1016/S0305-750X(98)00136-3.)

Aggarwal, P. K., Joshi, P. K., Ingram, J. S. I. \& Gupta, R. K. 2004 Adapting food systems of the Indo-Gangetic plains to global environmental change: key information needs to improve policy formulation. Environ. Sci. Policy 7, 487-498. (doi:10.1016/j.envsci.2004.07.006.)
Alexandratos, N. 1995 World agriculture: towards 2010 an FAO study. Chichester, UK: Wiley.

Amthor, J. S. 2001 Effects of atmospheric $\mathrm{CO}_{2}$ concentration on wheat yield. Field Crops Res. 73, 1-34. (doi:10.1016/ S0378-4290(01)00179-4.)

Arntzen, J., Muchero, M.T., \& Dube, P. 2004 Global environmental change and food provision in southern Africa: explorations for a possible GECAFS research project in southern Africa. GECAFS southern Africa Planning Workshop, Cape Town, 13-15 September 2004. See www. gecafs.org.

Babu, R. C., Shashidhar, H. E., Lilley, J. M., Thanh, N. D., Ray, J. D., Sadasivam, S., Sarkarung, S., O'Toole, J. C. \& Nguyen, H. T. 2001 Variation in root penetration ability, osmotic adjustment and dehydration tolerance among accessions of rice adapted to rainfed lowland and upland ecosystems. Plant Breeding 120, 233-238. (doi:10.1046/j. 1439-0523.2001.00578.x.)

Barling, D. 2004 Food systems: food policy and governance perspectives. GECAFS Food Systems Workshop, 21-22 October 2004. See www.gecafs.org.

Bohle, H.-G. 2001 Vulnerability and criticality: perspectives from social geography. IHDP Update, 2/2001. Bonn: IHDP.

Boudreau, T. 1998 The Food Economy Approach: a framework for understanding rural livelihoods. RRN Network Paper 26. London: Overseas Development Institute.

Brklacich, M. \& Bohle, H.-G. 2005 Assessing human vulnerability to climatic change. In Earth system science in the Anthropocene: emerging issues and problems (ed. T. Kraft \& E. Ehliers). Berlin: Springer.

Bruinsma, J. 2003 World agriculture: towards 2015/2030. London: Earthscan Publications Ltd.

Champoux, M. C., Wang, G., Sarkarung, S., Mackill, D. J., O’Toole, J. C., Huang, N. \& McCouch, S. R. 1995 Locating genes associated with root morphology and drought avoidance in rice via linkage to molecular markers. Theor. Appl. Genet. 90, 969-981. (doi:10.1007/BF00222910.)

Ellis, F. 2003 Human vulnerability and food insecurity: policy implications. The Forum for Food Security in Southern Africa ODI, London. See www.odi.org.uk.

Evans, L. T. 1998 Feeding the ten billion: plants and population growth. Cambridge, UK: Cambridge University Press.

FAO. 1996 Report of the World Food Summit, FAO, Rome.

Fischer, G., Shah, M., van Velthuizen, H. \& Nachtergaele, F. O. 2001 Global agro-ecological assessment for agriculture in the 21st century. Laxenburg, Austria: International Institute for Applied Systems Analysis.

Fischer, G., van Velthuizen, H., Shah, M. \& Nachtergaele, F. O. 2002 Global agro-ecological assessment for agriculture in the 21 st century: methodology and results. Research report RR-02-02. International Institute for Applied Systems Analysis, Laxenburg, Austria. p. 119+CD-ROM.

Fischer, G., Shah, M. \& van Velthuizen, H. $2002 b$ Climate change and agricultural vulnerability. Special report as contribution to the World Summit on Sustainable Development, Johannesburg 2002. Austria: International Institute for Applied Systems Analysis p. 152

Fischer, G., Shah, M., Tubiello, F. \& van Velhuizen, H. 2005 Socio-economic and climate change impacts on agriculture: an integrated assessment, 1990-2080. Phil. Trans. R. Soc. B 360, 2067-2083. (doi:10.1098/rstb.2005.1744.)

Francis, C. et al. 2003 Agroecology: the ecology of food systems. F. Sustain. Agric. 22, 99-118. (doi:10.1300/ J064v22n03_10.)

Fuhrer, J. 2003 Agroecosystem responses to combinations of elevated $\mathrm{CO}_{2}$, ozone and global climate change. Agric. Ecosyst. Environ. 97, 1-20. (doi:10.1016/S0167-8809(03) 00125-7.)

Gillespie, H. \& Gillespie G. W. Jr. 2000. Cornell Community Nutrition Program, Division of Nutritional Sciences, 
Cornell University, Community Food Systems: towards a common language for building productive partnerships. See www.ccc.cornell/programs/foodsystems.

Goodman, D. 1997 World-scale processes and agro-food systems: critique and research needs. Rev. Int. Polit. Econ. 4, 663-687.

Grace, P. R., Jain, M. C., Harrington, L. \& Robertson, G. P. 2003 The long-term sustainability of tropical and subtropical rice and wheat systems: an environmental perspective. In Special issue on improving the productivity and sustainability of rice-wheat systems: issues and impacts (ed. J. K. Ladha et al.), pp. 27-43. Madison, USA: American Society of Agronomy, Crop Science Society of America, Soil Science Society of America.

Gregory, P. J. 1989 The role of root characteristics in moderating the effects of drought. In Drought resistance in cereals (ed. F. W. G. Baker), pp. 141-150. Wallingford, UK: Commonwealth Agricultural Bureau International.

Gregory, P. J. 2004 Agronomic approaches to increasing water use efficiency. In Water use efficiency in plant biology (ed. M. A. Bacon), pp. 142-170. Oxford, UK: Blackwell Publishing.

Gregory, P. J. \& Ingram, J. S. I. 2000 Global change and food and forest production: future scientific challenges. Agric. Ecosyst. Environ. 82, 3-14. (doi:10.1016/S0167-8809(00) 00212-7.)

Gregory, P. J. et al. 1999 Managed production systems. In The terrestrial biosphere and global change: implications for natural and managed systems (ed. B. Walker, W. Steffen, J. Canadell \& J. S. I. Ingram), pp. 229-270. Cambridge, UK: Cambridge University Press.

Gregory, P. J. et al. 2002 Environmental consequences of alternative practices for intensifying crop production. Agric. Ecosyst. Environ. 88, 279-290. (doi:10.1016/S01678809(01)00263-8.)

Grievink, J. W. 2003 The changing face of the global food industry. OECD conference on changing dimensions of the food economy: exploring the policy issues, The Hague, 6 February 2003. webdomino1.oecd.org/comnet/agr/foodeco.nsf/ viewHtml/index/\$FILE/GrievinkPPT.pdf.

Hume, D., Moore, K. \& Shepherd, A. 2001 Chronic poverty: meanings and analytical frameworks. CPRC working paper 2. Manchester: Chronic Poverty Research Centre.

Ingram, J. S. I., Gregory, P. J. \& Brklacich, M. (eds) 2005 GECAFS science plan and implementation strategy. ESSp report, Wallingford, vol. 2.

Jones, P. G. \& Thornton, P. K. 2003 The potential impacts of climate change on maize production in Africa and Latin America in 2055. Global Environ. Change 13, 51-59. (doi:10.1016/S0959-3780(02)00090-0.)

Long, S. P., Ainsworth, E. A., Leakey, A. D. B. \& Morgan, P. B. 2005 Global food insecurity. Treatment of major food crops with elevated carbon dioxide or ozone under large-scale fully open-air conditions suggest recent models may have overestimated future yields. Phil. Trans. R. Soc. B 360, 2011-2020. (doi:10.1098/rstb.2005.1749.)

Mahendra Dev, S., Ravi, C., Viswanathan, B. Gulati, A. \& Ramachander, S. 2004 Economic liberalisation, targeted programmes and household food security: a case study of India. IFPRI Markets, Trade and Institutions Division, Discussion Paper No. 68, Washington DC, USA

Matson, P. A., Parton, W. J., Power, A. G. \& Swift, M. J. 1997 Agricultural intensification and ecosystem properties. Science 277, 504-509. (doi:10.1126/science.277.5325.504.)

McClain-Nhlapo, C. (2004). Implementing a Human Rights Approach to Food Security. International Food Policy Research Institute, 2020 Africa Conference Brief 13.
Millstone, E. \& Lang, T. 2003 The Atlas of food. London: Earthscan Publications Ltd.

Misselhorn, A. 2005 What drives food insecurity in southern Africa? A meta analysis of household economy studies. Global Environ. Change 15, 33-42. (doi:10.1016/j. gloenvcha.2004.11.003.)

Muchero, M. T. 2003 Distribution and consumption patterns. GECAFS workshop in southern Africa, 10-11 April 2003. See www.gecafs.org.

Mustafa, D. 1998 Structural causes of vulnerability to flood hazard in Pakistan. Econ. Geogr. 74, 289-305.

Nelson, M. \& Maredia, M. 1999 Environmental Impacts of the CGIAR: an initial assessment. Report prepared for the Impact and Evaluation Group of the CGIAR. IAEG Secretariat, UNOPS-FAO, Rome.

Neven, D. \& Reardon, T. 2004 The rise of Kenyan supermarkets and the evolution of their horticultural product procurement systems. Dev. Policy Rev. 22, 669-699. (doi:10. 1111/j.1467-7679.2004.00271.x.)

O’Toole, J. C. \& Bland, W. L. 1987 Genotypic variation in crop plant root systems. Adv. Agron. 41, 91-145.

Parry, M. et al. 2001 Millions at risk: defining critical climate change threats and targets. Global Environ. Change 11, 181-183. (doi:10.1016/S0959-3780(01)00011-5.)

Pingali, P., \& Khawaja, Y. 2004 Globalisation of Indian diets and the transformation of food supply systems. ESA working paper no. 04-05. Rome: FAO Economic and Social Department.

Porter, J. R. \& Semenov, M. A. 2005 Crop responses to climatic variation. Phil. Trans. R. Soc. B 360, 2021-2035. (doi:10.1098/rstb.2005.1752.)

Reardon, T., Timmer, C. P., Barrett, C. B. \& Berdegué, J. 2003 The rise of supermarkets in Africa, Asia and Latin America. Am. F. Agric. Econ. 85, 1140-1146. (doi:10.1111/j.00925853.2003.00520.x.)

Rosegrant, M. W. \& Cline, S. A. 2003 Global food security: challenges and policies. Science 302, 1917-1919. (doi:10. 1126/science.1092958.)

Scholes, R. J. \& Biggs, R. 2004 Ecosystem services in Southern Africa: a regional assessment. Pretoria, South Africa: Council for Scientific and Industrial Research.

Sidhu, R. S. 2005. Patterns and consequences of intensive agricultural growth in Punjab, India. Paper presented at GECAFS Indo-Gangetic Plain Workshop, Delhi 2-3 May 2005. See www.gecafs.org.

Smith, K. A., McTaggart, I. P. \& Tsuruta, H. 1997 Emissions of $\mathrm{N}_{2} \mathrm{O}$ and $\mathrm{NO}$ associated with nitrogen fertilization in intensive agriculture, and the potential for mitigation. Soil Use Manag. 13, 296-304.

Tilman, D. et al. 2001 Forecasting agriculturally driven global environmental change. Science 292, 281-284. (doi:10.1126/ science.1057544.)

Vogel, C. \& Smith, J. 2002 The politics of scarcity: conceptualising the current food security crisis in southern Africa. S. Afr. F. Sci. 98, 315-317.

Von Braun, J., Swaminathan, M. S. \& Rosegrant, M. W. 2004 Agriculture, food security, nutrition and the millenium development goals. Washington DC, USA: International Food Policy Research Institute.

Watts, M. J. \& Bohle, H.-G. 1993 The space of vulnerability: the causal structure of hunger and famine. Prog. Hum. Geogr. 17, 43-67.

Wisner, B., Blaikie, P., Cannon, T. \& Davis, I. 2004 At risk: natural hazards, people's vulnerability and disasters, 2nd edn. London: Routledge. 